\title{
Thin layer drying of tomato slices
}

\author{
Manashi Das Purkayastha • Amit Nath • \\ Bidyut Chandra Deka - Charu Lata Mahanta
}

Revised: 21 February 2011 / Accepted: 26 April 2011 /Published online: 1 June 2011

(C) Association of Food Scientists \& Technologists (India) 2011

\begin{abstract}
The hot air convective drying characteristics of blanched tomato (Lycopersicon esculantum L.) slices have been investigated. Drying experiments were carried out at four different temperatures $\left(50,60,65\right.$ and $\left.70{ }^{\circ} \mathrm{C}\right)$. The effect of drying temperatures on the drying behavior of the tomato slices was evaluated. All drying experiments had only falling rate period. The average effective diffusivity values varied from $0.5453 \times 10^{-9}$ to $2.3871 \times 10^{-9} \mathrm{~m}^{2} / \mathrm{s}$ over the temperature range studied and the activation energy was estimated to be $61.004 \mathrm{~kJ} / \mathrm{mol}$. In order to select a suitable form of the drying curve, six different thin layer drying models (Henderson-Pabis, Page, Diamante et al., Wang and Singh, Logarithmic and Newton models) were fitted to the experimental data. The goodness of fit tests indicated that the Logarithmic model gave the best fit to experimental results, which was closely followed by the HendersonPabis model. The influence of varied drying temperatures on quality attributes of the tomato slices viz. Hunter color parameters, ascorbic acid, lycopene, titratable acidity, total sugars, reducing sugars and sugar/acid ratio of dried slices was also studied. Slices dried at 50 and $60{ }^{\circ} \mathrm{C}$ had high amount of total sugars, lycopene, sugar/acid ratio, Hunter L- and $a$-values. Drying of slices at $50{ }^{\circ} \mathrm{C}$ revealed
\end{abstract}

M. Das Purkayastha $(\bowtie) \cdot$ C. L. Mahanta

Department of Food Processing Technology, Tezpur University, Napaam, Sonitpur,

Tezpur, Assam, India 784028

e-mail: manashi.daspurkasyasthya@gmail.com

A. Nath • B. C. Deka

Division of Horticulture,

ICAR Research Complex for NEH Region,

Umiam, Meghalaya 793103, India optimum retention of ascorbic acid, sugar/acid ratio and red hue, whereas, drying at higher temperature $\left(65\right.$ and $70^{\circ}$ C) resulted in a considerable decrease in nutrients and colour quality of the slices.

Keywords Tomato - Drying curve - Activation energy · Drying model $\cdot$ Lycopene $\cdot$ Ascorbic acid

\section{Introduction}

The demand of tomato in the country is increasing day-byday with the increase in population and its preference for tomato. However, tomato is highly perishable in the fresh state leading to wastage and losses during the peak harvesting period. The prevention of these losses and wastage is of major interest especially when there is subsequent imbalance in supply and demand at the harvesting off-season. These growing market opportunities have necessitated that tomatoes be accessible in a more convenient form and thus led to the development of technologies for the preservation and sale of the product especially in a dry form (St George et al. 2004).

Dehydration processes offer an alternative way of providing tomato to commerce. The most popular method of drying tomato is hot air drying due to its operation simplicity and relatively inexpensive technology (Akanbi et al. 2006). This technique employs flow of heated air stream (usual operational temperature range between 50 and $80^{\circ} \mathrm{C}$ ) to supply heat to the food and remove its moisture (Phongsomboon and Intipunya 2009). Tray drying (TD) is commonly used for drying of vegetables, and it was chosen because of its simplicity 
and low cost. TD is also often used in R\&D laboratories to simulate industrial tunnel or conveyor dryers (Nindo et al. 2003). In addition, determining the drying behavior by accurate mathematical models is important. Several mathematical models may be used to describe the drying process and help in its optimization, and assist in the effective design of dryers (Vega et al. 2007). Empirical equations frequently used to model the drying kinetics of food include: Newton, Page, Henderson-Pabis, Page modified, Logarithmic, Two-terms exponential, Thomson, Diffusion approach, Verma, Wang and Singh, HendersonPabis modified models and others (Meisami-asl et al. 2010; Vega et al. 2007). Recently, Diamante et al. (2010) proposed a new thin-layer drying model which gave the best curve fitting ability compared to the three widely used models, namely, Henderson-Pabis, Page and Logarithmic models, in kiwifruit and apricot.

Though dehydrated tomato products has commonly been obtained by hot air drying, which allows rapid and massive processing, but the maintenance of nutritional and commercial quality of such products through this process presents some problems (Argyropoulos et al. 2008). Undesirable changes in the colour may lead to a decrease in its quality and marketing value, therefore, the surface colour of the dried tomato product is an important criterion. So, the removal of moisture must be accomplished in a manner that will be least detrimental to the product quality. An understanding of the nutritional and colour changes of tomato slices during hot air drying is essential for any optimization study.

The aim of this research was the study and modelling of the drying kinetics of mass transfer during the hot-air convective drying process of blanched tomato slices. The effect of drying temperatures on the quality attributes of the dried slices was also studied for determining the optimum drying temperature that might produce high-quality dried tomato slices.

\section{Materials and methods}

Fully ripe tomato, cv. Punjab Kesri was procured from local vegetable market, and then washed under running water to remove the adhering impurities. Fruits of similar size, shape and free from injury were selected for the experiment. All the chemicals used were of analytical grade.

Pre-drying treatment Blanching was done by holding tomatoes in muslin cloth in boiling water (at $100{ }^{\circ} \mathrm{C}$ ) for $60 \mathrm{~s}$. Blanching adequacy was checked by using $0.5 \%$ guaiacol solution and $1 \mathrm{ml} 0.08 \% \mathrm{H}_{2} \mathrm{O}_{2}$ (Icier et al. 2006). Blanched tomatoes were cut into slices of $2 \pm$ $0.1 \mathrm{~cm}$ thickness (Doymaz 2008; Gupta and Nath 1984) using a vegetable slicer (Suan Scientific Instruments \& Equipments, Kolkata, India), and the slices were then divided into four lots: one for drying at $50{ }^{\circ} \mathrm{C}$, second for drying at $60{ }^{\circ} \mathrm{C}$, third for $65^{\circ} \mathrm{C}$ and fourth for $70{ }^{\circ} \mathrm{C}$.

Drying experiments Drying of the tomato slices was performed in a tray dryer (Suan Scientific Instruments \& Equipments, Kolkata, India), having an accuracy of $\pm 2{ }^{\circ} \mathrm{C}$. Each lot of blanched tomato slices were spread evenly over the trays in single layer. The experiments were conducted in 3 replications at 50,60, 65 and $70{ }^{\circ} \mathrm{C}$ of drying air temperatures, with constant drying air velocity of $1.1 \mathrm{~m} / \mathrm{s}$. The samples were weighed at $15 \mathrm{~min}$ interval for the first $1 \mathrm{~h}$, at $30 \mathrm{~min}$ interval for next $2 \mathrm{~h}$, and at $60 \mathrm{~min}$ interval for next $3 \mathrm{~h}$. The weight loss was recorded at particular intervals by a digital balance (A-200DS Digital Analytical Balance, Denver Instruments, Germany) of $\pm 0.05 \mathrm{~g}$ accuracy. Moisture content of tomato slices before and after drying was determined by the hot-air oven method (AOAC 1990), which was expressed as gram water/gram dry matter. The moisture content of the fresh tomato was $1479.5 \%$ (db). The drying was kept continued (for 5-6 h) till dry, non-sticky products were obtained. Attention was paid to ensure that the samples were not charred. So, the termination of drying process in each of the four cases, was based on the result of the visual analysis of the texture and colour of the dried product (Enujiugha and Akanbi 2008; Prakash et al. 2004), which was performed by a group of panelists (results not shown). Concomitantly, the final moisture content in the dried slices varied in the range of $12-17 \%(d b)$, which was in conformity with the results of several authors (Ashebir et al. 2009; Baloch et al. 1997; Brooks et al. 2008).

Analysis of the drying data Drying rate $(D R)$ on mass basis moisture content (dry basis), $M_{d b}$ at any time during the drying process was calculated by (Basavaraj et al. 2008):

$D R=\left(W_{i-1}-W_{i}\right) /\left(W_{d} \times \Delta t\right)$

$M_{d b}=\left[\frac{W_{i}-W_{d}}{W_{d}}\right] \times 100$

where, $W_{d}$ is the final mass of the sample (in grams); $W_{i}$ is the mass of the sample at time $t_{i}$ (in min) and $\Delta t$ is the difference between $t_{i-1}$ and $t_{i}$.

Moisture ratio of samples during drying is generally calculated by the following equation (Sawhney et al. 2009):

$M R=\left(M-M_{e}\right) /\left(M_{o}-M_{e}\right)$ 
where, $M R$ is moisture ratio, $M$ is the moisture content ( $\mathrm{g}$ water/g dry matter) at any time $t ; M_{o}$ is initial moisture content (g water/g dry matter) at time $t=0 ; M_{e}$ is material equilibrium moisture content ( $g$ water/g dry matter). During thin-layer drying of tomato slices in convective bed dryer, the samples were not exposed to uniform relative humidity continuously. Moreover, the values of $M_{e}$ are relatively small compared to $M$ and $M_{o}$, hence the error involved in the simplification is negligible (Doymaz 2007). So the moisture ratio was simplified to (Arumuganathan et al. 2009):

$M R=\frac{M}{M_{o}}$

The drying curve for each evaluated drying temperature was obtained by plotting the $M R$ of the sample versus the drying time (Velić et al. 2007).

Calculation of effective moisture diffusivity and activation energy For the tomato slices; the integrated equation of Fick's second law of diffusion was used for slab geometry in one dimension, representing only the first term of the development of the series in Eq. 5 (Doymaz 2007; Vega et al. 2007).

$M R=\left(\frac{8}{\pi^{2}}\right) \exp \left(\frac{-\pi^{2} D_{e f f} t}{4 L^{2}}\right)$

where, $D_{\text {eff }}$ is the effective diffusivity coefficient $\left(\mathrm{m}^{2} / \mathrm{s}\right) ; L$ is the half of slab thickness $(0.01 \mathrm{~m}$ in present study) and $t$ is time elapsed during drying (in sec). Rearranging Eq. 5, we get:

$\ln (M R)=(-0.209)-\left[\left(\frac{\pi^{2}}{4 L^{2}}\right)\left(D_{e f f} t\right)\right]$

From Eq. 6, when $\ln (M R)$ versus $(t)$ was plotted, a straight line with a slope $k_{\mathrm{o}}$ (Eq. 7) was obtained and the effective diffusivity coefficient, $D_{\text {eff }}$ was calculated.

$k_{o}=\frac{\pi^{2} D_{e f f}}{4 L^{2}}$

The diffusivity dependence on the temperature can be represented by the Arrhenius equation (Eq. 8) (TundeAkintunde and Afon 2010; Arumuganathan et al. 2009; Doymaz 2007), where, $D_{\text {eff }}$ is effective moisture diffusivity $\left(\mathrm{m}^{2} / \mathrm{s}\right), D_{\mathrm{o}}$ is constant pre-exponential factor of the Arrhenius equation $\left(\mathrm{m}^{2} / \mathrm{s}\right)$ (measured as intercept at $\mathrm{y}$ axis), $E_{a}$ is activation energy $\left(\mathrm{kJ} \mathrm{mol}^{-1}\right), \mathrm{R}$ is universal gas constant $\left(8.314 \mathrm{Jmol}^{-1} \mathrm{~K}^{-1}\right), \mathrm{T}$ is absolute temperature (Kelvin, K).

$D_{e f f}=D_{o} \exp \left(-\frac{E_{a}}{R T}\right)$
Equation 8 can be linearized as:

$\ln \left(D_{e f f}\right)=\ln \left(D_{o}\right)-\frac{E_{a}}{R T}$

The activation energy, $E_{a}$ can be determined from the slope $\left(E_{a} / \mathrm{R}\right)$ of the plot $\left(\ln D_{\text {eff }}\right)$ vs $(1 / \mathrm{T})$ using Eq. 9.

Modelling of drying curves Experimental moisture ratio values versus drying time were fitted by means of six models widely used to model drying kinetics of most food, namely, Henderson-Pabis model (Eq. 10) (Doymaz 2007), Page model (Eqs. 11 or 12) (Sawhney et al. 2009), Diamante et al. model (Eq. 13) (Diamante et al. 2010), Wang and Singh model (Eq. 14) (Wang et al. 2007), Logarithmic model (Eq. 15) (Arumuganathan et al. 2009) and Newton model (Eq. 16) (Vega et al. 2007).

$M R=A_{o} \exp (-k t)$

$M R=\exp \left(-k t^{N}\right)$

Page model (Eq. 11) was further linearized as Eq. 12 (Ahmed and Shivhare 2001):

$\ln [-\ln (M R)]=\ln k+N \ln t$

$\ln (-\ln M R)=a+b(\ln t)+c(\ln t)^{2}$

$M R=1+A t+B t^{2}$

$M R=A_{L} \exp (-k t)+C_{L}$

$M R=\exp (-k t)$

where, $A_{o}$ is Henderson-Pabis model coefficient (dimensionless constant); $N$ is Page model coefficient (dimensionless constant); $a, b$ and $c$ are constants (dimensionless) of Diamante et al. model; $A$ and $B$ are constants (dimensionless) of Wang and Singh model; $A_{L}$ and $C_{L}$ are constants (dimensionless) of Logarithmic model; $k$ is drying constant (per $\min ) ; t$ is time (min).

Adequacy of drying models The models were fitted to the drying data using Excel curve-fitting computer program (Windows 2007) and XLSTAT software (version 7.5.2, Addinsoft, New York). Non-linear regression analysis was used to estimate the parameters of those six thin layer drying models (Eqs. 10-16). The goodness of fit of the tested models to the experimental data was evaluated with the coefficient of correlation $(R)$, coefficient of determination $\left(R^{2}\right)$, sum of squared residuals (SSR), average residual $\left(e_{\text {ave }}\right)$, reduced chi-square $\left(\chi^{2}\right)$, root mean square error (RMSE) and mean relative percent deviation 
modulus $(P)$. The $e_{\text {ave }}, \chi^{2}, R M S E$ and $P(\%)$ can be calculated as follows:

$e_{\text {ave }}=\sum_{i=1}^{n} \frac{\left|M R_{\mathrm{exp}, i}-M R_{\text {pre }, i}\right|}{n}$

$\chi^{2}=\frac{\sum_{i=1}^{n}\left(M R_{\exp , i}-M R_{p r e, i}\right)^{2}}{n-z}$

$R M S E=\left[\frac{1}{n} \sum_{i=1}^{n}\left(M R_{\exp , i}-M R_{p r e, i}\right)^{2}\right]^{1 / 2}$

$P(\%)=\frac{100}{n} \sum_{i=1}^{n}\left|\frac{M R_{\exp , i}-M R_{p r e, i}}{M R_{\exp , i}}\right|$

where, $M R_{\text {exp }, i}$ and $M R_{\text {pre }, i}$ are $i$ th experimental and $i$ th predicted moisture ratios, respectively, ' $n$ ' is number of observations, and ' $z$ ' is number of drying constants in the model. The higher the $R$ and $R^{2}$ values and the lower the $e_{\text {ave }}, \chi^{2}, R M S E$ and $P(\%)$ values, the better is the fitness. The value of $P(\%)$ less than 5.0 indicate an excellent fit, while values greater than 10 are indicative of a poor fit (Singh et al. 2006; De Temmerman et al. 2008). As $e_{\text {ave }}, \chi^{2}$, and RMSE approach zero, the closer the prediction is to experimental data (Roberts et al. 2008).

Quality evaluation Colour of fresh tomatoes and dried tomato slices were measured by Hunter Color Difference Meter (Color Quest XE, Hunter Lab, USA). The instrument (including $65^{\circ} / 0^{\circ}$ geometry, D25 optical sensor, $10^{\circ}$ observer, specular light) was calibrated with black and white tiles provided by the manufacturer. Colour was expressed in Hunter Lab units: $L(100=$ bright, $0=$ dark $), a(+a=$ red, $-a=$ green $)$ and $b(+b=$ yellow, $-b=$ blue). In addition, total colour difference $(\Delta E)$ and hue angle $\left(\mathrm{h}^{\circ}\right)$ were calculated. Total colour difference $(\Delta E)$ indicates the magnitude of colour difference between fresh tomato and dried slices. Hue angle $\left(h^{\circ}\right)$ values represent the degree of redness, yellowness, greenness, and blueness; the maximum is at $0,90,180$, and 270, respectively (Patras et al. 2009).

$\Delta E=\left[\left(L-L_{o}\right)^{2}+\left(a-a_{o}\right)^{2}+\left(b-b_{o}\right)^{2}\right]^{1 / 2}$

$h^{o}=\tan ^{-1}(b / a)$

where fresh tomato was used as the reference $\left(L_{\mathrm{o}}, a_{\mathrm{o}}, b_{\mathrm{o}}\right)$ and a larger $\Delta E$ denotes greater colour change from the reference material.
Ascorbic acid content was determined by using 2,6dichlorophenol indophenols dye method (Ranganna 1986). Lycopene estimation was done by using AOAC (1990) method. The titratable acidity was estimated by titrating $5 \mathrm{ml}$ of the filtrate against $0.1 \mathrm{~N} \mathrm{NaOH}$ solution using phenolphthalein as an indicator. The acidity was calculated and expressed as percent anhydrous citric acid (AOAC 1990). Reducing sugars and total sugars were determined by the methods described by Ranganna (1986).

Statistical analysis All analyses were carried out in triplicate. The means and standard deviations were calculated. Statistical significance was established at $p<0.05$ by using $F$-test. A multivariate analysis of quality attributes of tomato slices dried at different temperatures was performed by Principal Components Analysis (PCA) biplot factor analysis with the Unscrambler ${ }^{\circledR}$ version 10.1 (Camo Inc., Oslo, Norway).

\section{Result and discussion}

Effect of air temperature on drying behavior The effect of four drying temperatures $\left(50,60,65\right.$, and $\left.70{ }^{\circ} \mathrm{C}\right)$ on the characteristic of drying curve and drying rate curve are depicted in Fig. 1a and b. The drying curves (Fig. 1a) show that moisture ratio decreases continuously with drying time. Figure $1 \mathrm{~b}$ indicates that the rate of removal of moisture was higher in the initial stage, which decreased thereafter under all the investigated conditions. At the initial stage of drying, the available free moisture concentration gradient was higher leading to higher drying rate. At high initial moisture content, the initial drying rate is always higher owing to higher vapor pressure gradient, which diminishes as drying progresses. This observed initial acceleration in drying may also be caused by an opening of the physical structure allowing rapid evaporation and transport of water. Similar changes in the shape of drying rate curves were observed by Wang et al. (2007), during thin layer drying of apple pomace. The variations in initial drying rates at different temperatures can be due to difference in masses, tray loads and air velocities. Such variations in drying rates were also found by Basavaraj et al. (2008) during thin layer hot air drying of fig fruit.

Increase in drying rate is associated with the increase in drying temperature (Thorat et al. 2010; Sawhney et al. 2009; Cano-Chauca et al. 2004). As such, the drying rate curves exhibited steeper slope from $50{ }^{\circ} \mathrm{C}$ to $65{ }^{\circ} \mathrm{C}$. However, the highest drying rate should have been found at $70{ }^{\circ} \mathrm{C}$, but it was obtained at $65{ }^{\circ} \mathrm{C}$ in the present study (Fig. 1b). This may be due to the use of high initial drying temperature that might have caused case-hardening effect, 
Fig. 1 Effect of drying temperatures on relationship between a Moisture ratio (MR) and drying time, b Drying rate and drying time for blanched tomato slices. Slices dried at $50{ }^{\circ} \mathrm{C}(\square)$; Slices dried at $60^{\circ} \mathrm{C}(\Delta)$; Slices dried at $65^{\circ} \mathrm{C}(\mathrm{X})$; Slices dried at $70{ }^{\circ} \mathrm{C}(\diamond)$

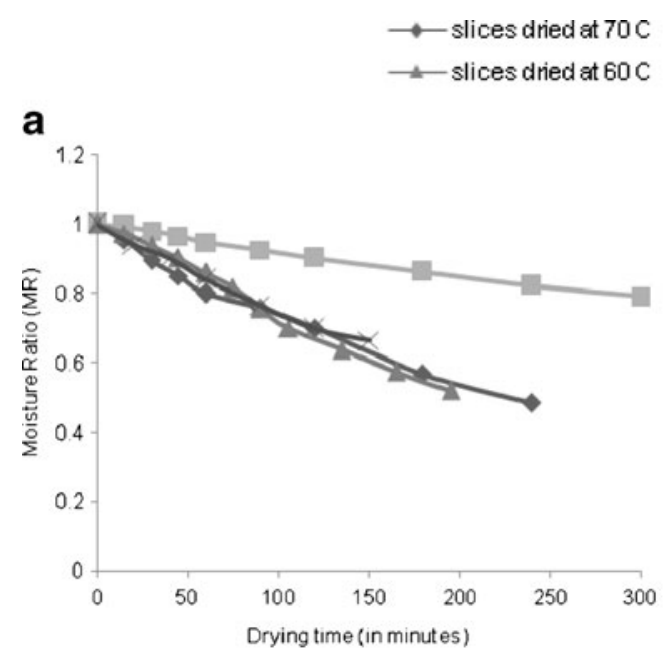

retarding movement of moisture from the inside to outside of the product. A constant rate period was not observed (Fig. 1b). Hence, it can be stated that the entire drying process occurred in the falling rate period in this study. This agrees with the report of Cano-Chauca et al. (2004). The falling rate region is indicative of an increased resistance to both heat and mass transfer through the inner cells and increased thickness of the crumpled and shrunken skin (Sawhney et al. 2009). More than one falling rate period has been observed (Fig. 1b), which indicates that tomato slices behaved like a hygroscopic food material during drying and the moisture movement inside the material was occurring by diffusion (Arumuganathan et al. 2009). These curves also showed extended falling rate periods to achieve low final moisture contents, which also prove that tomato slices will behave as hygroscopic products with high bound moisture contents. The point in the drying curve at which the two falling rate periods (Fig. 1b) are separated, corresponds to the moisture content of the inflexion point where the high drying rate is transformed into a low drying rate. During the first drying period, moisture content is greater in tomato slices and the movement of water is mostly by trans-membrane transport and the cell wall pathway (Phongsomboon and Intipunya 2009). So, the drying rate is higher. In the second drying phase, the moisture content is lower in tomato slices and the movement of water is mostly symplastic transport way and the drying rate is lower (Phongsomboon and Intipunya 2009).

Effective moisture diffusivity and activation energy The variation in $\ln (M R)$ and drying time $(t)$ for different temperatures have been plotted in Fig. 2 to obtain the slope $k_{o}$ (Eq. 7) which can give the effective moisture diffusivity $\left(D_{e f f}\right)$. The calculated values of effective diffusivity $\left(D_{\text {eff }}\right)$ for four different drying temperatures are $0.545255 \times 10^{-9}$, $2.38712 \times 10^{-9}, 1.91894 \times 10^{-9}$ and $2.02605 \times 10^{-9} \mathrm{~m}^{2} / \mathrm{s}$ for slices dried at 50,60, 65 and $70{ }^{\circ} \mathrm{C}$, respectively. The highest effective diffusivity value of $2.387 \times 10^{-9} \mathrm{~m}^{2} / \mathrm{s}$ was obtained for samples of $60{ }^{\circ} \mathrm{C}$ while the lowest $0.545 \times$ $10^{-9} \mathrm{~m}^{2} / \mathrm{s}$ was obtained for slices dried at $50{ }^{\circ} \mathrm{C}$. These values are within the general range of $10^{-6}-10^{-11} \mathrm{~m}^{2} / \mathrm{s}$ for drying of food materials (Arumuganathan et al. 2009). The obtained $D_{\text {eff }}$ values for tomatoes are similar to those estimated by different authors for tomatoes: 2.3-9.1 $\times$ $10^{-9} \mathrm{~m}^{2} / \mathrm{s}$ for tomatoes dried at $60-110{ }^{\circ} \mathrm{C}$ (Giovanelli et al. 2002), $3.72-12.27 \times 10^{-9} \mathrm{~m}^{2} / \mathrm{s}$ for tomatoes dried at $45-$ $75{ }^{\circ} \mathrm{C}$ (Akanbi et al. 2006); $0.87-1.0 \times 10^{-9} \mathrm{~m}^{2} / \mathrm{s}$ for cherry tomato dried at $40-60{ }^{\circ} \mathrm{C}$ (Varadharaju et al. 2001). These values are consistent with the present estimated $D_{\text {eff }}$ values for tomato slices. However, Doymaz (2007) found $D_{\text {eff }}$ in the range of $5.65-7.53 \times 10^{-10} \mathrm{~m}^{2} / \mathrm{s}$ at $55-70{ }^{\circ} \mathrm{C}$ for alkaline ethyl oleate solution pre-treated tomatoes and 3.91-6.65× $10^{-10} \mathrm{~m}^{2} / \mathrm{s}$ for untreated tomato samples, which are much lower than the estimated values of the present study.

Figure 3 shows the effect of temperature on effective diffusivity $\left(D_{\text {eff }}\right)$ of tomato slices, dried at different temperatures. Using Eq. 9, the activation energy value was found to be $61.004 \mathrm{~kJ} / \mathrm{mole}$, which was much higher than that

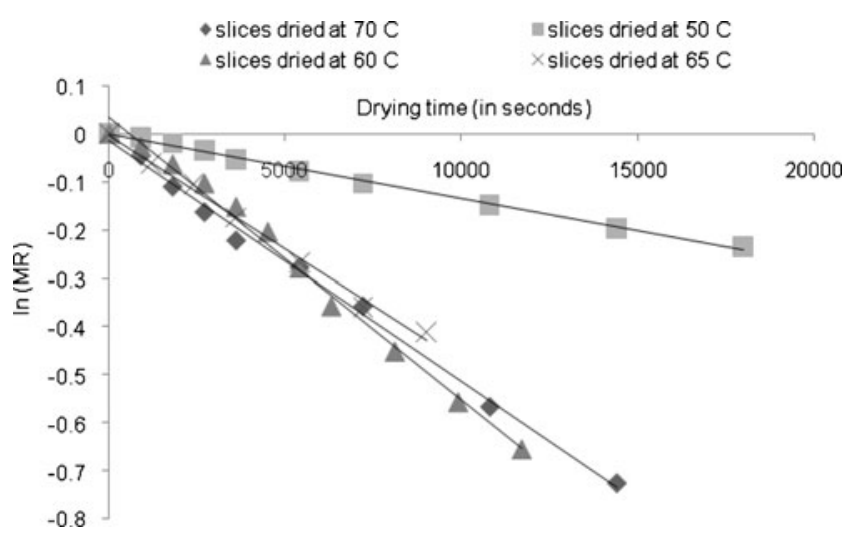

Fig. 2 Variation in $[\ln (M R)]$ and drying time (in seconds) for blanched tomato slices dried at different temperatures 


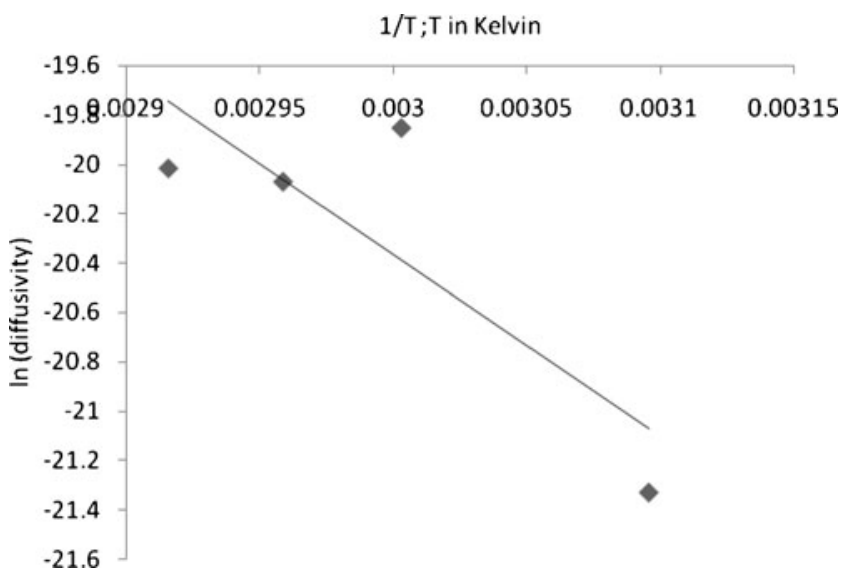

Fig. 3 Log plot of effective moisture diffusivity and drying temperatures ( $\mathrm{T}$ in Kelvin)

found by Doymaz (2007) in alkaline ethyl oleate solution pre-treated $(17.40 \mathrm{~kJ} / \mathrm{mole})$ and untreated $(32.94 \mathrm{~kJ} / \mathrm{mole})$ tomatoes. However, high value of activation energy (>73 kJ/mole) has been reported in milky mushroom drying (Arumuganathan et al. 2009). This variation might be because of the fact that in samples pretreated with blanching there is the occurrence of resistance to moisture migration as a result of gelatinization of starch granules or concentration effect of sugars (Tunde-Akintunde and Afon 2010). Because of similar reason, Doymaz (2010) also found higher activation energy value for blanched sweet potato slices compared to the unblanched (control) samples.

Modelling of drying kinetics For each investigated temperature, the experimental drying data were fitted in the Henderson-Pabis model (Eq. 10), Page model (Eq. 12), Diamante et al. model (Eq. 13), Wang and Singh model (Eq. 14), Logarithmic model (Eq. 15) and Newton model (Eq. 16). The values of the constants of these models and the results of their statistical analysis are summarized in Table 1. Figure $4 \mathrm{a}-\mathrm{f}$ show the variations of experimental and predicted moisture ratios by the Henderson-Pabis model, Page model, Diamante et al. model, Wang and Singh model, Logarithmic model, and Newton model, respectively, with drying time. It is evident from Table 1 that, in all drying temperatures, a good agreement between experimental data and chosen mathematical models exists, which is confirmed by their high values of $R$ and $R^{2}$ $(\geq 0.989)$, and low values of SSR (sum of squared residuals), $e_{\text {ave }}$ (average residual), $\chi^{2}$ (reduced chi-square), and RMSE (root mean square error). All the models exhibited $P(\%)$ values lesser than 5 , suggesting that the selected models gave excellent fit to the experimental data (Singh et al. 2006; De Temmerman et al. 2008). Though, $R$ and $R^{2}$ values of the all the six models were comparable with each other (Table 1), but the Logarithmic model gave the lowest SSR, $e_{\text {ave }}, \chi^{2}, R M S E$ and $P(\%)$ values for all the evaluated drying temperatures. So, the Logarithmic model may be assumed to represent the thin layer drying of blanched tomato slices in a convective hot air dryer. Logarithmic model was closely followed by the Henderson-Pabis model. Doymaz (2010) also found that the Logarithmic model showed the best fit to experimental drying data of unblanched and blanched sweet potato slices. Several investigators have also reported that the Logarithmic model adequately predicts the thin layer drying of a wide variety of agricultural products (Doymaz 2008; Khazaei and Daneshmandi 2007; Midilli and Kucuk 2003). Table 1 also shows that the drying constant $(k)$ of Page model increases with increase in air temperature, but no such trend was observed in $k$ values of other models. Sawhney et al. (2009), Ahmed and Shivhare (2001) also found a similar increasing trend of $k$ values for increase in temperature. Variation of other model coefficients with drying temperature was not systematic in the present study.

Effects of drying temperatures on quality attributes of tomato slices A perusal study of the Hunter colour parameters in Table 2 shows that Hunter $L$-value of the dried slices decreased with the increase in drying temperature. This indicates that the slices turned darker at higher temperature, which can be attributed mainly to browning reactions (Cernisev and Sleagun 2007). Hunter ' $+a$ ' value, which is considered as the benchmark in industry for the colour quality of tomato products, also decreased at higher temperature. Hunter ' $+a$ ' value was found maximum in the slices dried at $50{ }^{\circ} \mathrm{C}$ and $60{ }^{\circ} \mathrm{C}$, and least in slices of $70{ }^{\circ} \mathrm{C}$. Likewise, Hunter ' $+b$ ' value also decreased at higher drying temperatures, indicating a gradual decrease in yellow colour of the tomato slices. This is because total carotenoids and lycopene increase with increasing temperature. But at very high temperatures, $\alpha$-carotene, $\beta$-carotene, lutein, lycopene etc. starts degrading (Goula and Adamopoulos 2005). An increase in $\Delta E$ value was observed with increasing drying temperature. Table 1 shows the extent of colour change in the dried slices was lesser at 50 and $60{ }^{\circ} \mathrm{C}$. Based on CIELAB (Commission International de L'Eclairage) color system (Mapari et al. 2006), the hue angle $\left(h^{\circ}\right)$ of fresh tomato was 36.055 , signifying deep red colour. Drying of tomato slices at 50 and $60{ }^{\circ} \mathrm{C}$ resulted in a hue value of 33.444 and 25.294, which indicated red and red-pink colour of the dried slices, respectively. Further increase in drying temperature $\left(65\right.$ and $\left.70{ }^{\circ} \mathrm{C}\right)$ slightly increased the hue value to 30.244 and 32.494 , respectively, producing dry slices with light red colour. Thus, it can be inferred that drying of tomato slices at $50{ }^{\circ} \mathrm{C}$ can help preserve the attractive red hue of tomato, which is almost comparable with that of the fresh tomato sample.

The ascorbic acid content of fresh tomato was about $26.22 \mathrm{mg} / 100 \mathrm{~g}$ solid weight, and this value decreased as 


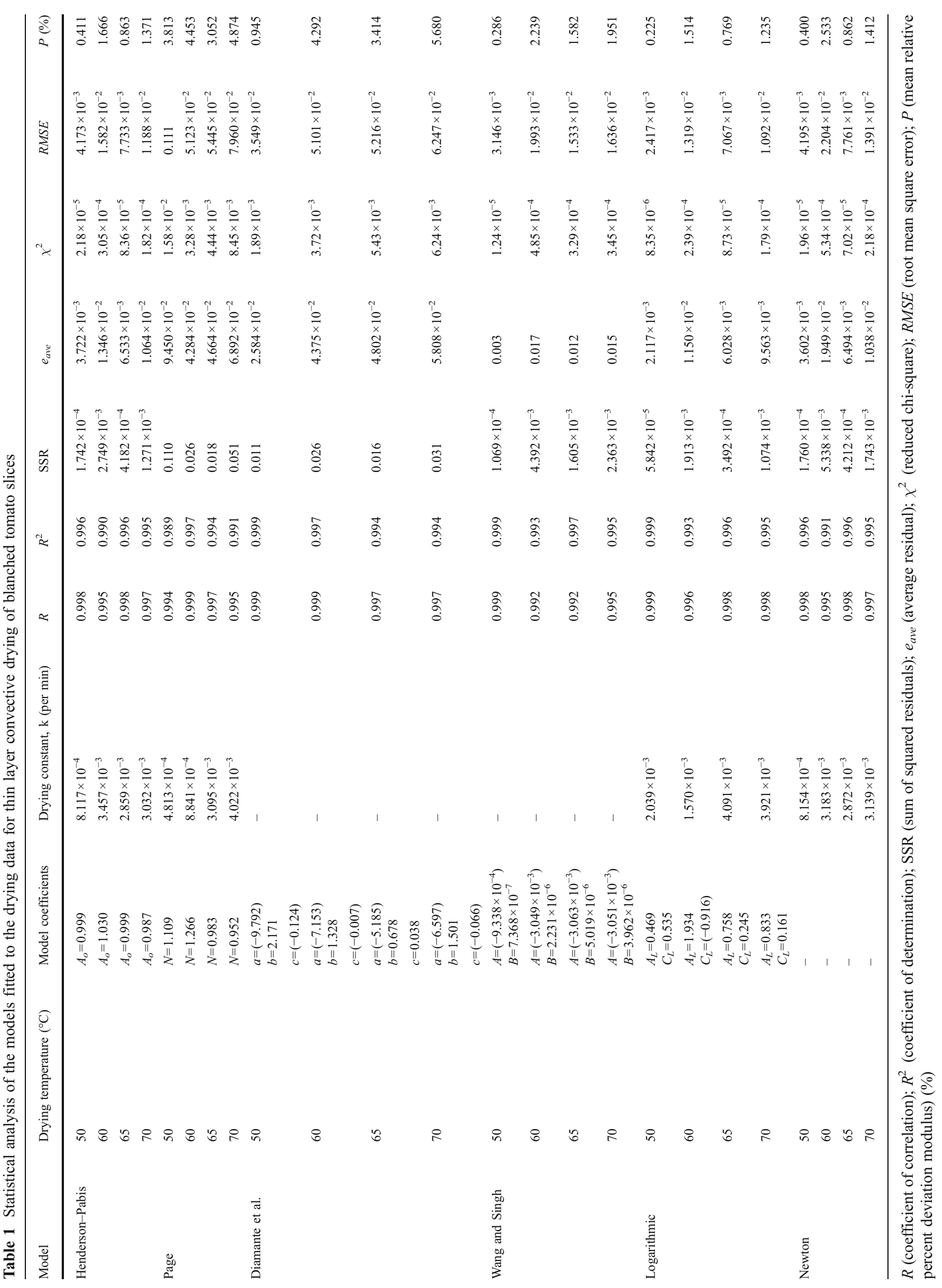


Fig. 4 Drying data fitted by a Henderson-Pabis model, b Page model, c Diamante et al. model d Wang and Singh model, e Logarithmic model, and f Newton model. Moisture ratio $(M R)$; Drying time $(t)$ (in minutes); Slices dried at $50{ }^{\circ} \mathrm{C}(\square)$; Slices dried at $60{ }^{\circ} \mathrm{C}(\Delta)$; Slices dried at $65^{\circ} \mathrm{C}(\mathrm{X})$; Slices dried at $70^{\circ}$ $\mathrm{C}(\diamond)$; Predicted model $(-)$

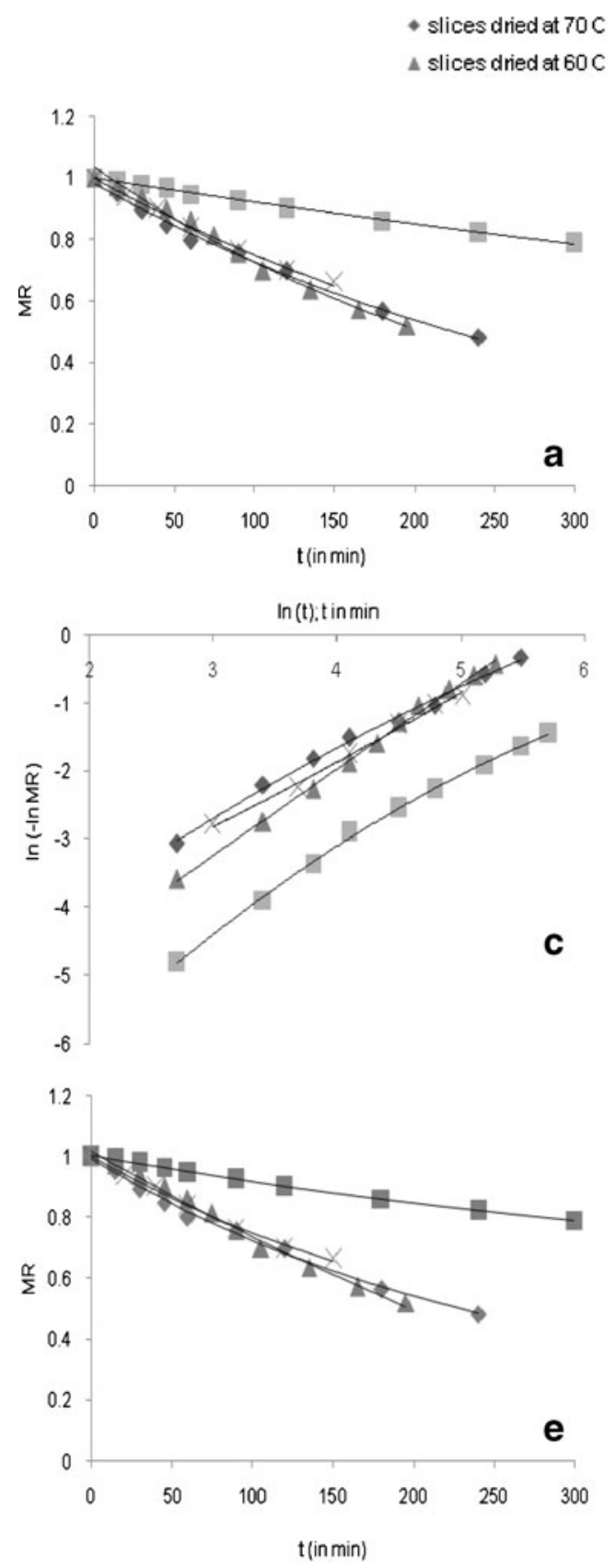

= slices dried at $50 \mathrm{C}$

$X$ slices dried at $65 \mathrm{C}$
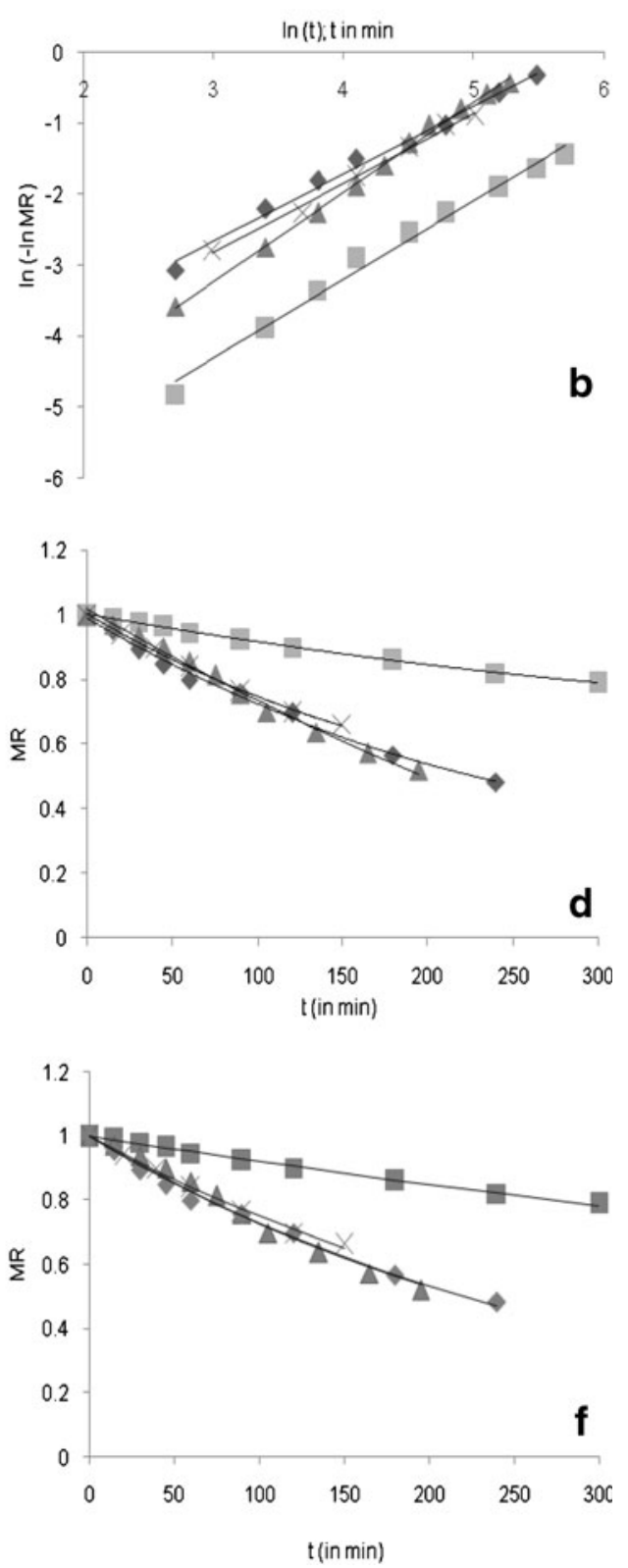

temperature increased during the drying of tomato slices (Table 2). The retention of ascorbic acid was nearly $64.44 \%, 39.45 \%, 32.51 \%$ and $13.15 \%$ for tomato slices dried at $50,60,65$, and $70{ }^{\circ} \mathrm{C}$, respectively. So, highest reduction in ascorbic acid occurred at $70{ }^{\circ} \mathrm{C}(86.85 \%)$ and lowest at $50{ }^{\circ} \mathrm{C}(35.56 \%)$. Therefore the present study indicates that slices dried at $50{ }^{\circ} \mathrm{C}$ were able to retain the heat-labile ascorbic acid better. Similar results were observed by Mudgal and Pande (2009) for bittergourd.

Lycopene content was higher in the dried tomato slices compared to the fresh tomato sample (Table 2). Maximum amount of lycopene was found in the slices dried at $60{ }^{\circ} \mathrm{C}$, beyond this temperature lycopene decreased. This increase can be attributed to the fact that high temperature treatments either stabilize or very slightly reduce the lycopene content of the fruit (Goula and Adamopoulos 2005). Lycopene content of slices dried at $60{ }^{\circ} \mathrm{C}(49.1 \mathrm{mg} / 100 \mathrm{~g})$ was 18.9 folds higher than that of fresh tomato $(2.6 \mathrm{mg} / 100 \mathrm{~g})$. As the drying temperature was increased from $60{ }^{\circ} \mathrm{C}$ to $70{ }^{\circ} \mathrm{C}$, lycopene decreased from $49.1 \mathrm{mg} / 100 \mathrm{~g}$ to $31.8 \mathrm{mg} / 100 \mathrm{~g}$ solid weight, indicating a loss of $35.23 \%$ within the temperature of $60-70{ }^{\circ} \mathrm{C}$. Nevertheless, the net increase in lycopene content of slices dried at $70{ }^{\circ} \mathrm{C}$ was still 12.2folds higher than fresh tomato. 
Table 2 Effect of drying temperatures on the physicochemical and Hunter colour characteristics ${ }^{\mathrm{a}}$ of tomato slices

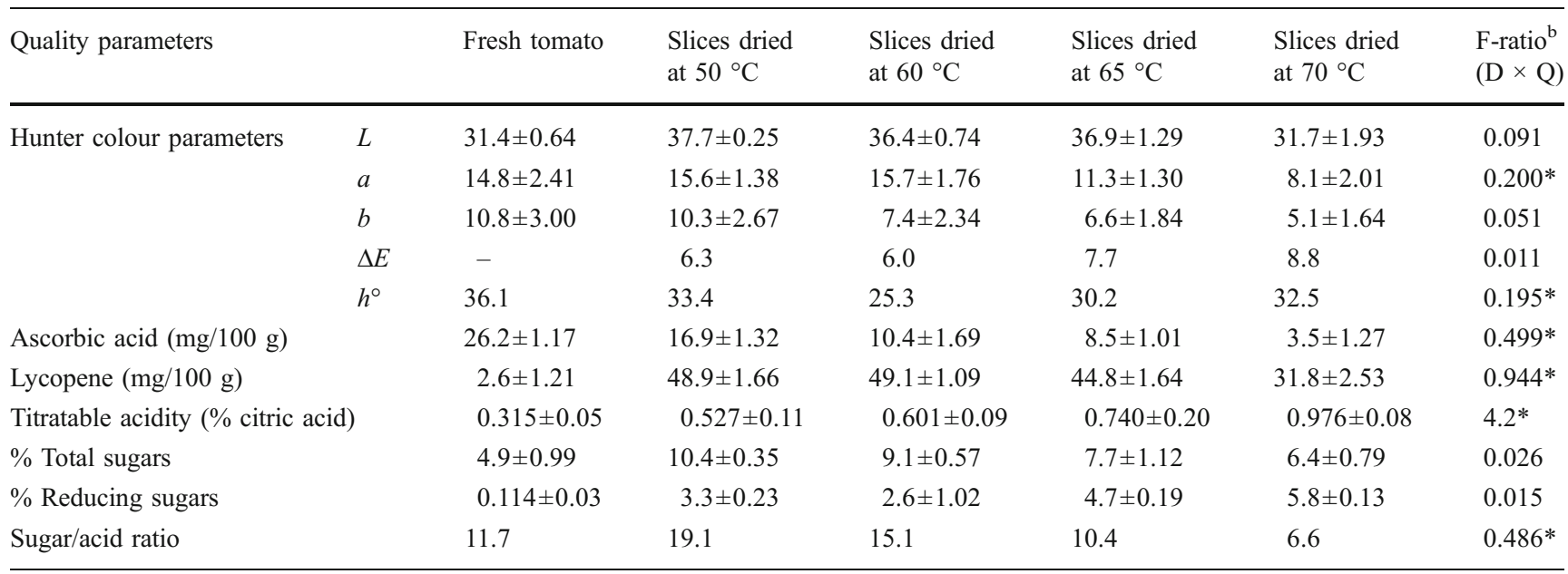

*Significant at $p<0.05$

${ }^{\text {a }}$ Values are mean \pm standard deviation of triplicate samples $(n=3)$

${ }^{\mathrm{b}}$ Degree of freedom $(\mathrm{df})=3$

$\mathrm{D} \times \mathrm{Q}$ : interaction of drying temperature and quality attributes

Titratable acidity increased with the increase in drying temperature (Table 2), the highest being observed in the tomato slices dried at $70{ }^{\circ} \mathrm{C}$. The titratable acidity of slices dried at $50,60,65$ and $70^{\circ} \mathrm{C}$ was $1.67,1.91,2.35$ and 3.10folds higher than the fresh tomato sample, respectively. During drying, increase in acidity was mainly attributed to the increased moisture loss from the sample with corresponding increase in temperature (Sagar et al. 2000).

Drying of tomato slices resulted in an increase in total sugar content (Table 2). The tomato slices dried at 50,60, 65 and $70{ }^{\circ} \mathrm{C}$ had $112.25 \%, 85.71 \%, 57.14 \%$ and $30.61 \%$ higher total sugar content than the fresh tomato sample, respectively. Increase in total sugar after drying can be attributed mainly to moisture loss and concentration effect (Gornicki and Kaleta 2007). The result shows that the highest amount of total sugar was found in the slices dried at $50{ }^{\circ} \mathrm{C}$; however, further rise in drying temperature caused a reduction in total sugar content. This might be because of inversion of sugars and browning reaction (Chawla and Ranote 2009).

Reducing sugar content in the dried tomato slices showed an increasing trend with the increase in drying
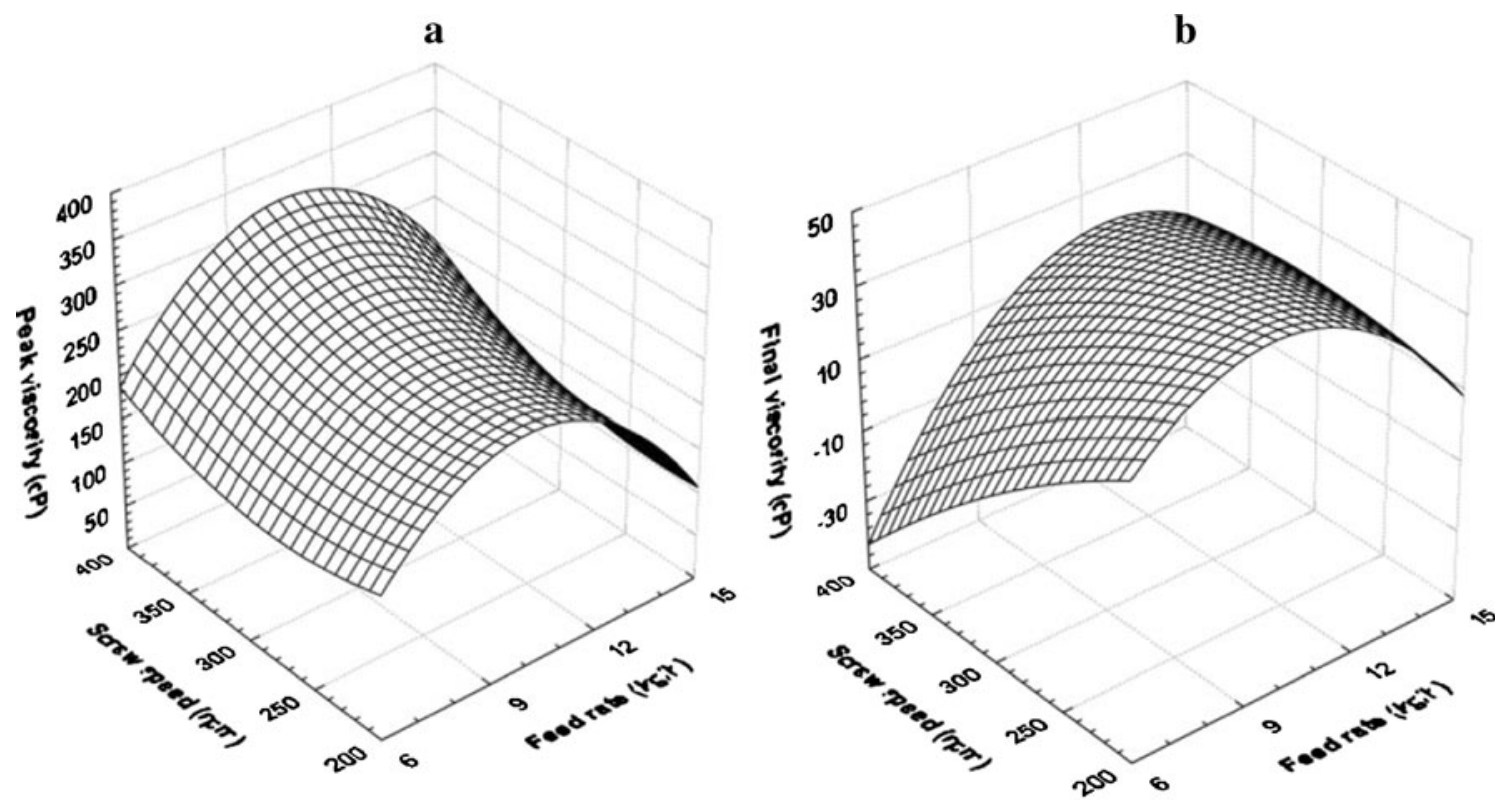

Fig. 5 Principal component analysis bi-plot of quality attributes of tomato slices dried at four different levels of temperature 
temperature (Table 2). Among the dried samples, highest and lowest amount of reducing sugar was found in slices dried at $70{ }^{\circ} \mathrm{C}$ and $50{ }^{\circ} \mathrm{C}$, respectively, which contained 50.88 and 28.95-folds higher reducing sugar than the fresh tomato. A probable explanation for such increase in reducing sugar level can be ascribed to rapid hydrolysis of polysaccharides and their subsequent conversion to reducing sugars at higher temperatures. Similar trend has been observed by Chawla and Ranote (2009) in dehydrated watermelon products.

Sugar/acid ratio was also higher in the dried tomato slices than the fresh tomato. A decreasing trend of sugar/acid ratio was observed in the slices as the drying temperature was increased. This can be attributed to the fact that with the increase in temperature, titratable acidity went higher, but total sugar content decreased and as such, the sugar/acid ratio also decreased. The highest sugar/acid ratio of 19.12 was found in slices made at $50{ }^{\circ} \mathrm{C}$. Studies have shown that higher sugar/acid ratio in tomato affects tomato taste attributes of the sweetness and sourness (Malundo et al. 1995; Stevens et al. 1979; Kader et al. 1977).

Level of the difference in dried slices To evaluate the effect of drying temperatures on ascorbic acid, lycopene content, titratable acidity, total sugars, reducing sugar, sugar/acid ratio, recovery of dried slices and Hunter colour parameters of the tomato slices, $F$-test was performed, following the work of Wang and Xi (2005) and the result is given in Table 2. The magnitudes of the $F$-values indicate the relative importance of the effect of temperature on these quality parameters. Drying temperatures significantly affected titratable acidity $(p<0.05)$. Based on the magnitudes of the $F$-values, it seems that varying temperature had a small effect on lycopene, ascorbic acid, sugar/acid ratio, Hunter $a$-values and hue angle. Temperature difference did not significantly affect the other investigated parameters.

Multivariate analysis Camargo et al. (2004) constructed a PCA sensory plot of dried tomatoes, which were pretreated with osmotic dehydration and antioxidant addition. The authors showed that taste had a positive relationship with purchase intention and for general appearance; the most important parameter was the colour. This indicates that the consumers give more importance to taste and colour, when buying dried tomato. Muratore et al. (2008) also stated that the market now shows increasing interest in tomato products with good nutritional characteristics. So, in the present study, a PCA biplot was constructed in order to determine the most suitable temperature range for producing dried tomato slices having higher amount of bioactive compounds (such as ascorbic acid and lycopene) as-well-as consumer acceptance related quality attributes (such as sugar/acid ratio and red colour hue). Principal components
(PC) 1 and 2 together represented $99 \%$ of the total variance with each PC accounting for $85 \%$ and $14 \%$ of the variances, respectively (Fig. 5). The distinction between the slices dried at different temperatures was clearly visible as the points were well-spread within the group in the biplot. Slices dried at $50{ }^{\circ} \mathrm{C}$ clearly showed better performance in terms of higher ascorbic acid content, sugar/acid ratio and red hue angle value, whereas those tomato slices which were dried at $60{ }^{\circ} \mathrm{C}$ were able to possess higher amount of lycopene. Such quality attributes in the slices of $70{ }^{\circ} \mathrm{C}$ were severely affected by the high drying temperature and as such, it was located far away from the rest of the samples in the biplot.

Thus, the PCA biplot discriminates the quality parameters of the tomato slices, dried at four different levels of temperature, more explicitly by spreading the points in the space across the two components $(\mathrm{PC} 1 \times \mathrm{PC} 2)$. The use of multivariate approach also validates the fact that drying of blanched tomato slices within a temperature range of 50 $60{ }^{\circ} \mathrm{C}$ will help in obtaining dry slices with optimum quality.

\section{Conclusion}

The drying temperatures were found to have a considerable effect on the moisture loss rates of the blanched tomato slices. Drying process occurred only in falling rate period under all the studied temperatures and more than one falling rate periods was also seen. Moisture removal from the slices was governed by diffusion phenomenon, as no constant drying rate period was observed. The effective moisture diffusivity ranged from $0.545 \times 10^{-9}$ to $2.387 \times$ $10^{-9} \mathrm{~m}^{2} / \mathrm{s}$. The activation energy required to detach and move the water out from tomato slices during the drying process was found to be $61.004 \mathrm{~kJ} / \mathrm{mole}$. Under the evaluated experimental conditions, the Logarithmic model provided the best representation of drying kinetics of blanched tomato slices, which was closely followed by the Henderson-Pabis model. The changes in the quality attributes of the dried tomato slices were dependent on the drying temperature. The results of the analysis of quality attributes of the dried slices, supported by PCA biplot analysis, showed that hot air convective drying of blanched tomato slices at 50 and $60^{\circ} \mathrm{C}$ can help in providing superior dried product in terms of colour and nutrient content, as opposed to higher drying temperatures.

Acknowledgements The authors are grateful to the faculty members, Research Associates especially Miss Bandita Bagchi and other staffs of the Division of Horticulture, ICAR Research Complex for NEH Region, Umiam, Meghalaya, India, for their constant support and valuable suggestions. Special thanks to Miss Reetamoni Das for her assistance with the manuscript preparation. 


\section{References}

Ahmed J, Shivhare US (2001) Effect of pre-treatment on drying characteristics and colour of dehydrated green chillis. J Food Sci Technol 38(5):504-506

Akanbi CT, Adeyemi RS, Ojo A (2006) Drying characteristics and sorption isotherm of tomato slices. J Food Eng 73:141-146

AOAC (1990) Official methods of analysis, 15th edn. Association of Official Analytical Chemists, Washington DC

Argyropoulos D, Heindl A, Muller J (2008) Evaluation of processing parameters for hot-air drying to obtain high quality dried mushrooms in the Mediterranean region. In: Conference on International Research on Food Security, Natural Resource Management and Rural Development, University of Hohenheim, Stuttgart, Germany, 7-9 Oct 2008

Arumuganathan T, Manikantan MR, Rai RD, Anandakumar S, Khare V (2009) Mathematical modeling of drying kinetics of milky mushroom in a fluidized bed dryer. Int Agrophys 23:1-7

Ashebir D, Jezik K, Weingartemann H, Gretzmacher R (2009) Change in color and other fruit quality characteristics of tomato cultivars after hot-air drying at low final-moisture content. Int J Food Sci Nutr 60(7):308-315

Baloch WA, Khan S, Baloch AK (1997) Influence of chemical additives on the stability of dried tomato powder. Int J Food Sci Technol 32(2):117-120

Basavaraj M, Prabhu Kumar GP, Sathyanarayana BR (2008) Determination of drying rate and moisture ratio of fig fruit (Ficus carica L.) by thin layer hot air drying method. J Food Sci Technol 45(1):94-96

Brooks MS, Abou El-Hana NH, Ghaly AE (2008) Effects of tomato geometries and air temperature on the drying behavior of plum tomato. Am J Appl Sci 5(10):1369-1375

Camargo GA, Moretti RH, Ledo CAS (2004) Quality of dried tomato pre-treated by osmotic dehydration, antioxidant application and addition of tomato concentrate. In: Drying 2004_Proceedings of the 14th International Drying Symposium (IDS 2004), São Paulo, Brazil, 22-25 August 2004, Vol C, pp 2207-2215

Cano-Chauca M, Ramos AM, Stringheta PC, Pereira JAM (2004) Drying curves and water activity evaluation of dried banana. In: Drying 2004-Proceedings of the 14th International Drying Symposium (IDS 2004), São Paulo, Brazil, 22-25 August 2004, Vol C, pp 2013-2020

Cernisev S, Sleagun G (2007) Influence of dehydration technologies on dried tomato biological quality and value. Cercetări Agronomice în Moldova, Vol. 3 (131). http://www.univagro-iasi.ro/ CERCET_AGROMOLD/CA3-07-07.pdf. Accessed 18 Sept 2010

Chawla R, Ranote PS (2009) Preparation and quality evaluation of dehydrated watermelon products. J Food Sci Technol 46(3):228-230

De Temmerman J, Verboven P, Delcour JA, Nicolaï B, Ramon H (2008) Drying model for cylindrical pasta shapes using desorption isotherms. J Food Eng 86:414-421

Diamante LM, Ihns R, Savage GP, Vanhanen L (2010) A new mathematical model for thin layer drying of fruits. Int J Food Sci Technol 45:1956-1962

Doymaz I (2007) Air-drying characteristics of tomatoes. J Food Eng 78:1291-1297

Doymaz I (2008) Influence of blanching and slice thickness on drying characteristics of leek slices. Chem Eng Process 47:41-47

Doymaz I (2010) Thin-layer drying characteristics of sweet potato slices and mathematical modelling. Heat Mass Transf. doi:10.1007/s00231-010-0722-3

Enujiugha VN, Akanbi CT (2008) Quality evaluation of canned fermented oil bean seed slices during ambient storage. Afr J Food Sci 2:54-59
Giovanelli G, Zanoni B, Lavelli V, Nani R (2002) Water sorption, drying and antioxidant properties of dried tomato products. J Food Eng 52:135-141

Gornicki K, Kaleta A (2007) Drying curve modelling of blanched carrot cubes under natural convection condition. J Food Eng 82:160-170

Goula AM, Adamopoulos KG (2005) Stability of lycopene during spray drying of tomato pulp. LWT Food Sci Technol 38(5):479-487

Gupta RG, Nath N (1984) Drying of tomatoes. J Food Sci Technol 21 (6):373-376

Icier F, Yildiz H, Baysal T (2006) Peroxidase inactivation and colour changes during ohmic blanching of pea puree. J Food Eng 74:424-429

Kader AA, Stevens MA, Albright-Holton M, Morris LL, Algazi M (1977) Effect of fruit ripeness when picked on flavor and composition in fresh market tomatoes. J Am Soc Hortic Sci 102(6):724-731

Khazaei J, Daneshmandi S (2007) Modeling of thin-layer drying kinetics of sesame seeds: mathematical and neural networks modeling. Int Agrophys 21:335-348

Malundo TMM, Shewfelt RL, Scott JW (1995) Flavor quality of fresh tomato (Lycopersicon esculentum Mill.) as affected by sugar and acid levels. Postharvest Biol Technol 6:103-110

Mapari SA, Meyer AS, Thrane U (2006) Colorimetric characterization for comparative analysis of fungal pigments and natural food colorants. J Agric Food Chem 54(19):7027-7035

Meisami-asl E, Rafiee S, Keyhani A, Tabatabaeefar A (2010) Determination of suitable thin layer drying curve model for apple slices (variety-Golab). POJ 3(3):103-108

Midilli A, Kucuk H (2003) Mathematical modeling of thin layer drying of pistachio by using solar energy. Energy Convers Manage 44(7):1111-1122

Mudgal VD, Pande VK (2009) Thin layer drying kinetics of bittergourd (Mimordica charantia L.). J Food Sci Technol 46 (3):236-239

Muratore G, Rizzo V, Licciardello F, Maccarone E (2008) Partial dehydration of cherry tomato at different temperature, and nutritional quality of the products. Food Chem 111:887-891

Nindo CI, Sun T, Wang SW, Tang J, Powers JR (2003) Evaluation of drying technologies for retention of physical quality and antioxidants in asparagus (Asparagus officinalis, L.). LebensmWiss Technol 36:507-516

Patras A, Brunton NP, Tiwari BK, Butler F (2009) Stability and degradation kinetics of bioactive compounds and colour in strawberry jam during storage. Food Bioprocess Technol. doi:10.1007/s11947-009-0226-7

Phongsomboon P, Intipunya P (2009) Comparative study on drying of osmotic treated carrot slices. As J Food Ag-Ind 2(04):448-456

Prakash S, Jha SK, Datta N (2004) Performance evaluation of blanched carrots dried by three different driers. J Food Eng $62: 305-313$

Ranganna S (1986) Handbook of analysis and quality control for fruit and vegetable products. McGraw Hill Publishing Co. Ltd, New Delhi

Roberts JS, Kidd DR, Padilla-Zakour O (2008) Drying kinetics of grape seeds. J Food Eng 89:460-465

Sagar VR, Khurdiya DS, Maini SB (2000) Quality of ripe mango powder as affected by storage temperature and period. J Food Sci Technol 37(2):165-168

Sawhney RL, Pangavhane DR, Sarsavadia PN (2009) Drying studies of single layer Thompson Seedless Grapes. In: International Solar Food Processing Conference. http://www. solarfood.org/solarfood/.../solarfood2009/3.../49 Sahwaney. pdf. Accessed 30 Aug 2010

Singh B, Panesar PS, Nanda V (2006) Utilization of carrot pomace for the preparation of a value added product. World J Dairy Food Sci $1(1): 22-27$ 
St George SD, Cenkowski S, Muir WE (2004) A review of drying technologies for the preservation of nutritional compounds in waxy skinned fruit. In: 2004 North Central ASAE/CSAE Conference, Winnipeg, Manitoba, Canada, Paper Number: MB04-104, 24-25 Sept 2004. http://www.docentes.unal.edu.co/ hamartinezco/docs/Tecnicas\%20de\%20Preservacion.pdf. Accessed 27 Aug 2010

Stevens MA, Kader AA, Albright M (1979) Potential for increasing tomato flavor via increased sugar and acid content. J Am Soc Hortic Sci 104(1):40-42

Thorat ID, Mohapatra D, Sutar RF, Kapdi SS, Jagtap DD (2010) Mathematical Modeling and Experimental Study on ThinLayer Vacuum Drying of Ginger (Zingiber officinale R.) slices. Food Bioprocess Technol. doi:10.1007/s11947-0100429-y
Tunde-Akintunde TY, Afon AA (2010) Modelling of hot-air drying of pretreated cassava chips. Agric Eng Int: CIGR Journal 12(2):34-41

Varadharaju N, Karunanidhi C, Kailappan R (2001) Coffee cherry drying: a two-layer model. Drying Technol 19:709-715

Vega A, Fito P, Andrés A, Lemus R (2007) Mathematical modeling of hot-air drying kinetics of red bell pepper (var. Lamuyo). J Food Eng 79:1460-1466

Velić D, Bilic M, Tomas S, Planinic M, Bucic-Kojic A, Jokic S (2007) Study of the drying kinetics of "Granny Smith" apple in fluid bed dryer. ACS 72(4):329-334

Wang J, Xi YS (2005) Drying characteristics and drying quality of carrot using a two-stage microwave process. J Food Eng 68:505-511

Wang Z, Sun J, Liao X, Chen F, Zhao G, Wu J, Hu X (2007) Mathematical modeling on hot air drying of thin layer apple pomace. Food Res Int 40:39-46 